\title{
WHY LOCAL RESIDENTS HARVEST NATURAL FOREST? DETERMINANTS FACTORS IN THE MOUNTAINS OF KHYBER PAKHTUNKHWA
}

\author{
Fazli Rabbi \\ Department of Economics and Development Studies University of Swat \\ Shahid Ali \\ Department of Economics and Development Studies University of Swat \\ Umar Hayat \\ Department of Economics and Development Studies University of Swat \\ Zia Ullah \\ Institute of Business Management (IoBM)
}

\begin{abstract}
Purpose: - This paper empirically examines households' forest biomass extraction behavior in three forests areas of Khyber PakhtunKhwa, Pakistan. It further identifies the determinant factors of three types of resources that have implications for forest cover. These include the extraction of fuel wood, cutting of timber and free grazing of goats in the forests.

Methodology: - We use primary date collected from 180 households in three forest areas (Miandam, Lalkoo, and Bamburet in the province of Khyber Pakhtunkhwa. The data was gathered in three Miandam, Lalkoo, and Bamburet using two stage sampling technique.

Findings: - The results showed that as insecurity of forest ownerships, family size and age of the households increases, households are more likely to opt for fuel wood harvesting from the forests. On the contrary, as education of the household head, no of crops grown in a season distance to market, use of substitute fuel, and plantation on private land outside forest and livestock assets increases, households are less likely to harvest fuel wood from the natural forests. We also find that there cross regional variation in tendency to harvest fuel wood from the forests. The results also reveal that, households tendency to graze in the forest decreases as households' off-farm income share increases in total households annual income.

Practical Implication: - The government forest policy and conservation efforts need to prioritize the provision of alternative fuel sources, community plantation. Policy strategies are needed to regulate free grazing of goats socially in the state owned natural forests in the province. The areas in the periphery of the natural forests should be supplied with sources of energy from substitute sources such as hydroelectric powers, launch community plantation programs vis-à-vis legislate to resolve the issue of dispute of forest ownership to realize the goal of sustainable utilization of forest and socioeconomic development of the mountains regions.
\end{abstract}

Key Words: Forest, Insecurity, Harvest, Socioeconomic Development

Jel Classification: $\mathrm{O} 40, \mathrm{O} 44, \mathrm{O} 18$

*The material presented by the author does not necessarily portray the view point of the editors and the management of the Institute of Business \& Technology - IBT

1. Fazli Rabbi : rabbi.fazli@gmail.com

2. Shahid Ali : Shahid_aerc@yahoo.com

3. Umar Hayat : umarhayat@uswat.edu.pk

4. Zia Ullah : zia.ullah@iobm.edu.pk

CIBT-JBS is published by the Institute of Business \& Technology - IBT

Main Ibrahim Hydri Road, Korangi Creek, Karachi-75190, Pakistan 


\section{INTRODUCTION}

In Pakistan, according to government figures, only 4.8 percent of the total land area is covered with natural forests. Recent figures from the World Development Indicators (WDI,2014) indicates that forest area constituted $2.7 \%$ of the total land which further declined to $2.1 \%$ in 2012. This loss of forests disrupts the ecosystem and increases environmental stress, as has been witnessed in the country during the last 30 years (Rowley, 1990). The problem is more severe in the province of Khyber Pakhtunkhwa (formerly known as NWFP), where 40 percent of the country's natural forests are located. In the province, some areas are faced with increasing forests loss. For example in Miandam valley the natural forests are declining at an annual average rate of 1.37 percent to 6.13 percent, which caused the areas of natural forests in the area to decline from 3500 hectares to nearly 2500 hectares during 1978-2001.The devastating flood of July, 2010, is described as one of the main cause of declining forest and vegetation cover in the north of Khyber Pakhtunkhwa province. Studies also suggest that if this current rate of forest degradation continues unabated, this part of the province will lose its forest resources by the year 2025 (Steimann, 2003).

As natural forests are important sources of living. According to Rabbi and Bauer (2007), local communities are heavily dependent on the forests. In the mountains, where these natural forests are found, alternative source of energy do not exist, subsistence farming is practiced where only a single crop is grown. The farmers' access to market is limited and there are very few opportunities of off-farm income in these areas. The majority of the population is poor, who depends on livestock rearing for home consumption and generation of cash income. Livestock rearing is entirely dependent on fodder from the natural forests. Different plant species are also harvested from these natural forests to fulfill the dietary needs of the family. As the natural forests have dwindled over time, it has created adverse implications for the livelihoods of the forest dependent communities. Moreover, many important fauna and flora species have already become extinct (Khan, 2005).

The first important factor for decreasing forest cover is the cutting of trees for timber (commercial and domestic) and tree felling for fuel wood. The process of forest degradation further accelerated after the provincial in 1992 put a ban on commercial timber harvesting after the area was hit by floods. Since, commercial harvesting is a source of revenue for the landowners who are entitled to 60 percent of the amount received from the sale of timber by the government while 40 percent accrue to the government. The continuous ban on commercial sale of timber over the years, affected the revenues of the landowners. It also affected the local households' use of fuel wood as commercial timber harvesting produced extra quantities of fuel wood for the local households. This created mistrust between the government and landowners. Consequently, the landowners began to sell forest trees clandestinely to timber smugglers and contractors. The forest offenses increased in2005, in two forest divisions, Matta Forest Division (MFD) and Swat Forest Division (SFD), about 10,691 forest offences of illegal cutting were registered by the forest officials, in court against the forest offenders. The monetary value of the loss caused by illegal felling was estimated to be Rs.12, 962, 377 (158464.26 US\$). Out of the above-mentioned cases, only 27 cases with a monetary value of Rs. 283470 (3465.40 US\$) were in October 2005, while many are still pending in the local courts (FD, 2005).

The second important factor that leads to degradation of natural forest is the free grazing of cattle, goats and sheep. This practice leads to the damage of newly regenerated seedlings of 
conifer species as well as loss of other plant species of important economic value. The plant cover is significantly reduced due to free grazing. A study on the impact of free grazing on forest cover showed that 840 tree seedlings/hectare were found in natural forests areas with no grazing, whereas, only 66 tree seedlings/hectare were found in areas of natural forests, where goats are grazed freely (Khan et al. 2007). Due to overgrazing, demographic and economic pressure natural forests are under the threat of degradation (Maselliet al. 2005).

In fact, forest resource extraction has existed for centuries in the North of Khyber Pakhtunkhwa province. However, the natural forests were better conserved during the reign of former King of Swat State (1948-69). Fuel wood and timber for domestic consumption were allowed, however prior approval of the State authorities was required. In the State times, better forest management strategies of the State ensured sustainable use of the forests and minimized forest offenses. Grazing in the natural forests was also regulated in the King's time. However, after the merger of Swat State with Pakistan in 1969, the natural forests in the areas started to be over exploited and excessive timber felling occurred mostly because of the unclear land rights especially in forests.

After the merger of the Swat State with Pakistan, the management of the natural forest was entrusted to the provincial Forest Department, which followed the colonial authoritative management of the forests. There was a lack of participatory approaches and local landowners were excluded from decision making with respect to forest resource management. Realizing the alarming rate of deforestation, efforts were made in the 90's to ameliorate the forest loss and improve the socioeconomic condition of the forest dweller communities in Khyber Pakhtunkhwa province. As a practical step in this regard, Malam Afforestation Project (MAP), 1997, the Environmental Rehabilitation Project (ERP), 1994, Malakand Social Forestry Project (MSFP), Dir Area Support Program (DASP), Project for Horticulture Promotion (PHP) 1988, was launched in the area. Kalam Integrated Development Project (KIDP), was a milestone in the development of mountains in upper Swat, nonetheless it role in the sustainable use of forests and halting forest degradation is not very impressive.

Several studies have focused the problem of deforestation. For example Rome (2005) has excellently described the historical realities about the forest use and management in princely State of Swat, while Steinman (2003) has examined the devolution and Joint Forest Management in Lalkoo valley in Khyber Pakhtunkhwa. Khan (2005) analyzed the trend of forest degradation using Geographic Information System (GIS) and found that forest in some areas have significantly recued during 1978-2001. Nevertheless, households level consumption of forest resource such fuel wood, timber cutting and grazing have not been focused in these studies. In fact, the forest communities are highly dependent on the forest as source of energy and income. This is because of the lack of alternative source of energy for fuel and income in these remote packets of the province. This paper adds to the literature an important aspect of forest use in the Khyber Pakhtunkhwa, an aspect previously not been focused in the context of the province. The major objective of the research is to analyze the factor that determine the extraction of fuelwood, timber cutting and grazing in the natural forests, which adversely affect the natural forest cover in the area.

The paper is organized as follows: In the next section, we describe the data and research methodology. Moreover, the study sites and data analysis are also briefly introduced in this section. Results and discussion are given in fourth section. The last section concludes and provides some policy implications. 


\section{Data}

The study was conducted in three mountainous valleys- Miandam, Lalkoo, and Bamburet in the province of Khyber Paktunkhwa, Pakistan (Formerly known as NWFP). The valley has growing stock of 120,079 trees with an annual yield or supply of 2,037 trees from all working circles.About 203,328 cubic feet timber that equal 877 trees and 2,828,750 $\mathrm{kg}$ of fuel wood that equal 581 mature trees is exported to other areas (Adnan et al. 2006). The natural forests of Miandam are grouped as moist temperate forests (Raashid 1999). In Lalkoo valley, the important forest tree species are Fir (abies spp.), Spruce (Piceasmithiana) and Blue Pine (Pinuswallichiana). Bamburet valley is located about $36-40 \mathrm{Km}$ from Chitral town in Khyber Paktunkhwa. Pine (Pinusgerardiana) and Deodar (Cedrusdeodara) are the dominant species the natural forest of Bamburetforests. . The valley is also known as Kalash valley as the inhabitants mostly belong to famous community known as Kalash. It is also known as Kafiristan valley (Valley of infidels). The natural forests in the area are also abundant with medicinal plants providing cash income to the people. Nearly, $80 \%$ of the households in the valley are dependent on fuelwood harvested from the natural forests. An estimated 25 to 30 thousands metric tons of forest wood is used for fuel at homes. We designed a structure interview schedule for the households. Before the actual data collection the questionnaire was pre-tested and some of the questions were found irrelevant and unfit to the actual field situations. These questions were removed and the questionnaire was refined. Face to face interviews were held with head of the households in three sites. The interviews schedule consisted of respondents personal information, demographic information of the households, income and consumption, assets holdings, access to forests and questions forest resources extraction. A two stage sampling technique was used. In the first stage, the study site was purposely selected. In the second stage household lists were obtained from the local union council office and randomization was done to selected households for interviews. Out of the Union Council List, a total 80 household heads were interviewed in Site 1 (Miandam Valley), 100 households were interviewed in Site 2 (Lalkoo valley) and 50 households were interviewed in Site 3 (Bamburet Valley). Nevertheless, due to missing information, the date of 180 questionnaires was found to be useful. We finally used the data of 180 households for analysis. The data enumerators were trained to explain the purpose of the survey to the respondents so that accurate information collected could be ensured. In cases of doubt in the data we verified the information from the key information having knowledge of the households in the villages. Semi- structure interviews were also held with the elders in the villages at the study sites on the use and patter of fuel wood, timber and grazing in the forest.

\section{Methodology and Analysis}

This study used binary logistic regression to analyze the determinants of fuelwood harvesting, timber cutting and grazing at the household level. The analytical framework of Reardon and Vosto (1995) is used for the selection of the explanatory variables that affect the harvesting of fuel wood, timber cutting and free grazing in the natural forests. Besides, other studies report that household demographic characteristics, asset endowments, access to institutions, distance to market, accessibility to resources and geographical location influence resource extraction among the forest dwelling communities (Coomes, et al. 2004). The choice of explanatory variables are also consistent with Fisher, et al. (2005) Godoy, (2001), Perz and Walker (2004), Perz et al. (2005), Swinton and Quiroz (2003) and Takasaki, et al. (2001) who have included in their analysis on resource extraction especially among forest dwelling communities 


\section{Model Specification and Estimation}

Household harvesting of fuel wood, cutting of timber and grazing in the natural forest takes the form of a choice decision. In the questionnaire the household were asked three questions: (1) whether a particular household harvest fuel wood from the natural forest or not. Dummy variable was created takingthe value ' 1 ' if a particular household reported fuel wood harvesting and '0' otherwise.(2) Whether a particular household cut trees for timber from the natural forest or not. Dummy variable was created taking the value ' 1 ' if a particular household reported tree cutting and ' 0 ' otherwise. (3) Whether a particular household cut tree for timber from the natural forest or not. Dummy variable was created taking the value ' 1 ' if a particular household reported tree cutting and ' 0 ' otherwise

Since the response to the questions of fuel wood, timber and grazing is 'Yes' and 'No'. These are used as dependent variables in the three models. Since the dependent variables are dummy, in such situations Binary logistic regression an appropriate technique. The binary logistic model is given as follow:

$$
Y_{i}^{*}=\beta_{0}+\sum_{j=1}^{k} \beta_{j} x_{i j}+u_{i}
$$

Where $Y_{i}^{*}$ is not observed. It is commonly called a Latent variable. What we observe is a dummy variable $Y_{i}$ defined by

$$
Y=\left\{\begin{array}{cc|}
1 & \text { if } Y^{*}>0 \\
0 & \text { otherwise }
\end{array}\right.
$$

Since the Dummy variable ' $Y$ ' is whether the household is harvesting fuel wood, timber cutting or grazes in the forest timber, or grazes in natural forest or not, then $Y^{*}$ is defined as the ability/inability of the household to harvest fuel wood, cut timber or grazing or not from natural forest. The explanatory variables in equation (1) would contain variables that explain the choice of harvesting ability, cutting timber / not harvesting, not cutting, not grazing From the system in equation (2) that multiplying $Y i^{*}$ by positive constant does not change $Y i$. Hence, if we observe $Y i$ we can estimate $\beta$ 's in equation (1) only up to a positive multiple. Hence it is customary to assume $\operatorname{var}(i)=1$. This fixes the scale of $Y i^{*}$.

From the relationship of equation (1) and (2) we get

$$
\begin{aligned}
& P_{i}=\operatorname{prob}\left(Y_{i}=1\right)=\operatorname{prob}\left[u>-\left(\beta_{0}+\sum_{j=1}^{k} \beta_{j} x_{i j}\right)\right] \\
& =1-F\left[-\left(\beta_{0}+\sum_{j=1}^{k} \beta_{j} x_{i j}\right)\right]
\end{aligned}
$$

Where, $F$ is the Cumulative distribution of $u$. If the distribution of $\mathrm{u}$ is symmetric,

Since, $1-F(-Z)=F(Z)$ we can write

$$
P_{i}=F\left(\beta_{0}+\sum_{j=1}^{k} \beta_{j} x_{i j}\right)
$$


The functional form of $F$ in equation (3) will depend on the assumption made about the error term $u$. If the cumulative distribution of $U i$ is logistic, we have what is known as the binary logistic model. In this case

$$
F\left(z_{i}\right)=\frac{\exp \left(z_{i}\right)}{1+\exp \left(z_{i}\right)}
$$

Hence $z_{i}=\log \frac{F\left(z_{i}\right)}{1-F\left(z_{i}\right)}$

For the binary logistic model; $\log \frac{p_{i}}{1-p_{i}}=\beta_{0}+\sum_{j=1}^{k} \beta_{j} x_{i j}$

The left hand side of the above equation is called the log-odd ratio. Hence, the log-odds ratio is a linear function of the explanatory variables (Maddala, 2001; Gujarati, 2004). For estimating the logit and probit models, the maximum likelihood estimation method is used because of its merits. In most of the economic studies, data comes from surveys, rather than controlled laboratory experiments, therefore, the maximum likelihood estimation is preferred over other methods and the logit model is used (Horowitz and Savin, 2001). Keeping in view the merits of the logit model, it is used to model household choice of fuel wood harvesting, timber cutting and grazing in the forest. In order to run the logistic regressions, STATA software 8.2 was used. The first logistic regression was run for fuel wood harvesting, the second for timber cutting and the third for grazing in the natural forests.

\section{RESULTS AND DISCUSSION}

Households size, access to forest resources, security of forest ownership, farm size, wealth (no. of goats), availability of substitute fuels, plantation on private farms, off-farm opportunities, access to markets and extension service have strong bearing on dependency and extraction of the forest resources among the forest dependent communities (Coomes, et al. 2004; Fisher, et al. 2005 Godoy, 2001; Perz and Walker 2004, Perz et al. 2005; Swinton and Quiroz 2003; and Takasaki, et al.2001). When household lack liquid assets, they self insure through forest based activities (Mc Sweeney, 2005). Forests in the province of Khyber Paktunkhwa supplement households' income derived from other activities and reduce income inequality among households (Rabbi, et al. 2010). The results from the binary logistic model show that, household fuel wood harvesting is positively and significantly $(p=0.01 *)$ related with the age of the household head. It is due to the fact, that old household heads utilizes their extra time for the harvesting of fuel wood for the household. Such heads of the households when free from other activities such as agricultural operations- harvesting, threshing collect fuel wood to keep a stock for the winter. The model results further show that, there is negative and significant $(\mathrm{p}=01)$ between household fuel wood harvesting and education of the household head. It implies that educated households' heads are less likely to harvest fuel wood from the natural forests. The relationship is significant at 10 percent probability level. These findings imply that households with more educated heads are less likely to opt for fuel wood harvesting from the natural forests. Similar findings have been reported in empirical studies conducted by Gunatileke (1998) and Adhikariet al. (2004). This entails conclusion that education, an important human capital can be very instrumental management strategy for reducing human extraction pressure on the natural forest, because a society with educated individuals have greater opportunities to get employment in other sectors (Gunatileke 1998, 
Vedeldet al. 2004). Households with educated members are likely to have a higher income and may buy alternative fuels and other forest products from the local markets instead of harvesting from natural forest on their own.

We find that, there is a significant and positive association between houeholdsfuelwood harvesting from the natural forests and family size. The underlying reason is that larger families have more demand of fuel wood as compared to small sized households. This dependency on forests and family size has also been reported in other studies (Mamo, et al. (2007, Quang and Anh, 2006, and Wickramasinghe, et al. 1996). These results support the arguments made in a study in Rwanda by Masozera (2002).

It is further evident from the results household fuel wood harvesting from natural forest and tenure insecurity of forest ownership are positively related. The relationship is significant at $10 \%$ probability level $(\mathrm{p}=01)$. The problem of insecurity of the forest ownerships provide a disincentive for the sustainable utilization of the natural forests as, households' uncertain of any future benefits from the natural forests prefer consumption and utilization of the resources to exploit the resource before someone else uses them. It is clear from the results that, households' fuelwood harvesting from the natural forest have a negative and significant relationship with the variable number of crops grown per season. The relationship is significant at 5\% level $(\mathrm{p}=001)$. Households who cultivate more crops per season are less likely to harvest fuel wood because they spend more time in farming. As most of the households who harvest fuel wood from the natural forests, sell fuel wood to earn cash income and to support the family consumption needs. While in case they practice farming, they could get income by selling the extra output as well as fulfill the consumption needs of the households.

A particular households' distance to the forest and fuelwood harvesting are inversely related and the relationship is significant at 1 percent probability level. The reasons is mainly due to the high opportunity cost of fuelwood harvesting. The households living near to the natural forests, have an easy access to the resources who harvest excessive amount of fuelwood from the natrual forests. This proximity of hoseholds to the natural forests leads to forest degradation (Khan 2005). Because of the increasing population pressures and demand for fuel energy in these remote areas. During the last few decades the natural forest near the villages in the study area is highly degraded further leading to fuelwood scarcity. Visual observations also showed a higher degree of degradation of the forests near human habitations. Our findings add to the literature on the association between forest resource extraction and accessibility to forest (Wickramasinghe, et al. 1996, Gunatileke and Chakravorty, 2003).

The results reveal that, there a negative and significant relationship between household distance to town markets and fuel wood harvesting from the natural forests. The relationship is significant at $5 \%$ level. This is due to household's inability to participate in labor markets and less opportunities of off-farm work in the mountains where natural forests are located. Households, who have limited access to external markets and infrastructure facilities are mostly poor and depend the forest resources in their vicinity (Masozera, 2002). Whereas, households living near to town may opt for fuel wood to buy from the market, because of the increasing opportunity cost. In addition households living near to town may have other sources of energy available to them in their vicinity. The results further indicate that household with more educated heads, multiple crops grown in a season, use of substitute fuel 
and ownership of farm plantation and more livestock assets are less likely to harvest fuel wood from the natural forests.

There is an inverse relationship between households' fuel wood harvesting and use of the substitute fuel. The relationship is significant at 10 percent probability level $(\mathrm{p}=01)$. It implies that households using fuel from alternative sources such as kerosene oil, and liquid petroleum gas are less dependent on fuel wood from the natural forests. The lack of alternative sources of fuel is one of the main causes of extraction of resource from the natural forests. (Bluffstone, 1998). A significant and negative relationship is found between households' fuel harvesting from the natural forests and households' plantation on private farms. The relationship is significant at $10 \%$ level. Tree plantation on private farms helps the households to meet the fuel wood needs of the households from the tree grown on private farm.

The results further indicate that households' ownership of goats (proxy for wealth) and fuelwood harvesting are negatively related. The relationship is significant at $10 \%$. This is attributed to the fact that households with more goats have alternative opportunities of income by selling products such as milk, cheese, wool, and animal hairs to earn cash income. Whereas, households that are poor in such assets, harvest fuel wood to satisfy their energy demands as well as to generate cash income. Livestock are relatively liquid assets that can be sold in time of need to mitigate household vulnerability to risk. Livestock have a crucial role in the rural mountains of Khyber Pakhtunkhwa. Other studies on similar aspects have found that, goat ownership reduce forest dependency (Fisher et al. 2005) in areas, where fuel wood harvesting leads to forest decline. The location dummy in the model indicates that households resident in Miandam area are less likely to harvest fuel wood from the natural forest. This is mainly attributed to the availability of other substitutes such as Kerosene and LPG that can be purchased from the local village market. In addition, the access to the town markets is comparatively better than the other two study sites.

\section{Determinants Households' timber harvesting}

The results show that household decision to cut trees from the natural forest has negative association with the age of the household head. The relationship is significant at $1 \%$ level. This implies that younger households are more likely to cut timber from the forest than older ones. Interestingly, there is no significant association between education of the head of the household and tree cutting. These results are in conformity with the findings by Gunatileke and Chakravorty (2003) and Mamoet al. (2007) who examined participation in forest resource extraction and education of the household;

The results also reveal that there is a positive and significant relationship between household's tree cutting for timber and insecurity of forest ownership. These results imply households who are uncertain of land title to the natural forests prefer to consume the resource in the current time. This insecurity of the forest ownership is a disincentive for sustainable use of the natural forests. This leads to deforestation as the expense of excessive tree cutting by these households for the short term benefits. In most cases, while discussing with key informants in the area, it was disclosed [as we do not know who will reap the benefits of the forests when these are sold, so we sell the forests tree to people who pays us the money.

The results of timber cutting model show that, there is significant and positive association between landholding and tree cutting. The relationship is significant at $1 \%$ level. This is attributed to the fact that land rich households' are mostly more endowed with assets and power to cut trees from the natural forests. Household with more lands are mostly, the rich people in the area who cut trees from the natural forests. The timber (high value forest 
product) is major cause of deforestation in the province of Khyber Paktunkhwa. The harvesting of fuel woodfrom the natural forests has an important effect on deforestation, but when large scale deforestation is taken into account, 30 percent is caused by commercial timber harvesting (Ali and Benjamensen, 2004). One major contributing factor to deforestation is cutting trees for timber, which is sold in other markets of the Khyber Paktunhkwa where it fetches a high price. This is mainly carried out by these land rich people. Similar results have also been reported which verify that high value output from natural forest is the domain of rich households (Mamo, et al., 2007). The extraction of timber is important in rich villages (Godoy et al. 1995).

The location dummy shows that timber cutting varies across geographical location and households' residents in Miandam are more likely to cut trees for timber than Lalkoo and Bamburet. These variations are attributed to that fact that in the Miandam area, there is a village market for timber sales and several influential people are involved in the timber trade. On the contrary, Bamburet valley is less accessible by road, which makes it difficult to transport the timber to the markets. The existence of local management institutions also help in the regulation of extraction of resources from the natural forests in Bamburet valley.

\section{Determinants of households' goats grazing}

The results of logistic regression of grazing activity show that, that household grazing choice is positively affected by the number of goats owned. The relationship is significant at 1 percent level. These findings support existing studies on the relationship between assets poverty and the environment. These findings suggest that wealthy households benefit more from environmental resources as compared to poor households. Similar findings have also reported in other countries. For example Mamoet al. (2007) found in a study in Ethiopia that livestock endowment significantly increases exploitation of fodder resources from communal. Their study indicates that the wealthy benefit more from fodder resources. In situation where grass becomes more abundant, household with large livestock endowment switch to grazing (Narain et al. 2005). The results further reveal an inverse relationship between household grazing choice and the share of off-farm income in total household annual income. The coefficient is significant at 1 percent probability level. Furthermore, the coefficient of access to extension and developmental projects is negative and significant at 1 percent level. This implies that better access to extension services reduces dependency on natural forest for fodder resources. This is due to provision of improved seeds for fodder to target households and awareness campaigns about the adverse impacts of grazing in the natural forest by developmental projects and extension services.

\section{Conclusions and policy implications}

This paper analyzed the declining forest cover of natural forest in three study sites in the province of Khyber Pakhtunkhwa, Pakistan. We conclude, the existing harvesting of fuel wood, timber cutting and free grazing is largely due to changing demographics, access to forest resources, lack of alternative source of energy, lack of liquid assets, limited opportunities of off-farm employment, lack of plantation programs and access to extension services in the areas. We further conclude that, the institutional factors such as insecurity of forest ownerships is one of the major factor leading to the over exploitation of the natural forests resources. It is further concluded that fuel wood harvesting- a source of energy and income is due to lack of off-farm job opportunities, remoteness from towns, subsistence farming (one crop per season), and alternatives sources of energy in the mountains of Khyber Paktunkhwa. Due to insecurity of land titles in forests, forest owners are inclined to harvest forest trees to earn revenues as in commercial timber harvesting they are declined of their due 
share in forest revenues in case of commercial logging by the state. The grazing practice in the natural forests is damaging the natural forest cover, which is practice by households having large herds of goats. Livestock particularly goats areintegral part of the livelihoods of the mountainous communities therefore such strategies are needed to increase productivity of the livestock farmers and regulate grazing in the natural forests. It is argued that, land rich households benefits more from the forest as they cut high value forest product (timber).

In light of the insights gained from this study, it is recommended that national forest policy should be taking into account the existing demographic, economic and institutional realities in the area. National developmental programs should be extended to the remote area to provide alternative sources of energy and income generation. The famers in the area should be facilitated to produce crops which could ensure more production and market value to reduce the dependency on the forest for generation of income.

The free grazing in the natural forests should be regulated through participatory approach to convince the herders to regulate free grazing of goats on natural forest, because large herd size leads to overgrazing and species loss (Swinton and Quiroz, 2003). The State Forest Department shall make plans for controlled grazing such as rotational systems with a participatory approach to involve local landowners and nomadic grazers. Plantation programs are needed to promote multipurpose trees. The farmers should be compensated for growing trees to promote plantation forests on private land, virgin and barren forest lands to provide incentives for the sustainable utilization of natural forest resources in the area. Monetary incentives in the form of revenues from the sale of timber are equitably distributed among the forest dwelling communities to develop them socioeconomically and realize the objective if sustainable use of the natural forests.

\section{ACKNOWLEDGEMENTS}

The authors are grateful to the households in the three forest communities who participated in the survey. We are also thankful to Dr.Inam-ur-Rahim, Mr. Ahmad Khan, Mr.Gohar, who helped in the field survey. Thanks are also extended to my friend Ms.VikiMirgon of Washington, United States, for her useful suggestions. The financial support offered by the German Academic Exchange (DAAD) is highly appreciated.

\section{REFERENCES}

Adhikari, B., Difalco, S., and Lovett, C.J. (2004). Household's Characteristics and Forest Dependency: Evidence from Common Property Management in Nepal. Ecological Economics, 48(2): 245-257.

Adnan, M., Khan, A.A., Latif, A., and Shinwari, Z.K. (2006). Threats to the Sustainability of Ethno-medicinal Uses in Northern Pakistan. A Case Study of Miandam Valley District Swat, NWFP Province, Pakistan. Journal of Ecology and Application, 11 (2): 91-100.

Ali, A., and Khawaja, N., (2003). The effect of Usage Regulation Governing Common Grazing Areas on the Livelihoods of Pastoralist Communities in Bamburet Valley of Chitral, Pakistan. Agha Khan Rural Support Program. Regional Program Office Chitral.

Bluffstone, R.A. Reducing Degradation of Forests in Poor Countries when Permanent Solutions elude Us: What Instruments do We Really Have. Environment and Development Economics, 1998; 3:295-317. 
Coomes, O.T., Barham, B.L., and Takasaki, Y. (2004). Targeting Conservation-Development Initiatives in Tropical Forests: Insights from the Analysis of Rain Forest Use and Economic Reliance among Amazonian Peasants. Ecological Economics, 51: 47-64.

Fisher, M., Shively, G.E. \& Buccola, S. (2005). Activity Choice, Labor allocation and Forest Use in Malawi. Land Economics, 81(4): 503-517

Forest Department (FD). (2005). Monthly Progress Report of Forest Offense Cases for the Month of October 2005. Office of the Divisional Forest Officer (DFO), District Swat, NWFP, Pakistan.

Godoy, R., Brokaw, N., and Wilkie, D. (1995). The Effect of Income on the Extraction of Non-Timber Tropical Forest Products: Model, Hypothesis, and Preliminary Findings from Sumu, Indian of Nicaragua. Human Ecology, 23(1):29-52.

Godoy, R., Kirby, K., and Wilkie, D. (2001). Tenure Security, Private Time Preferences, and Use of Natural Resources among Lowland Bolivian Amerindians. Ecological Economics, 38:105-118.

Gunatilake, H.H., and Chakravorty, U. (2003). Protecting Forests through Farming.A Dynamic Model of Non-timber Forest Extraction. Environmental and Resource Economics, 24: 1-26.

Gunatileke, H.H. (1998). The Role of Rural Development in Protecting Tropical Rainforest: Evidence from Sari Lanka. Environmental Management, 53(3): 273-292.

Gujarati, D.N., (2003). Basic Econometrics. $4^{\text {th }}$ Edition. The McGill Hill Companies, Americas, New York, NY, 10020.

Khan, Z., (2005). Mapping Deforestation in Miandam Valley of District Swat, during 19782001, using GIS and Remote Sensing.B.sc Forestry Thesis. (Unpublished), Forestry education Division, Pakistan Forest Institute, Peshawar.

Khan, A.A, Hussain, S.K., Haider, S. and Sher, H., (2007). Preliminary Results on the Nomadic Grazing on Floral Diversity in Miandam, Swat Pakistan.Unpublished Report of the World Wide Fund for nature.pp.1-08.

Kleinbaum, D.G., (1994). Logistic Regression-A Self Learning Text', Statistics in the Health Sciences.Springer-Verlag New York, Inc. pp.6-7.

Mamo, G., Sjaastad, E., and Vedeld, P. (2007). Economic Dependence on Forest Resources.A Case from Dendi District, Ethiopia. Forest Policy and Economics, 9: 916-927.

Maselli, D. Syfrig, E. and Rahim, I.U. (2005). Improving Small Ruminants Production. A Pathway to Better livelihoods in three tests Valleys in Pakistan. Mountain Research and Development, 25(2):104-108.

Masozera, M.K., (2002). Socioeconomic Impact Analysis of the Conservation of the Nyungwe Forest Reserve, Rawanda. Master of Science thesis of the Graduate School of the University of Florida. pp.1-112.

Masozera, MK. and Alavalpati, J. (2004). Forest Dependency and its Implications for Protected Areas Management: A Case of Study from the Nyungwe Forest Reserve, Rawanda. Scandinavian Journal of Forest Research, 19: 85-92 (Supplement 4).

Narain, U., Gupta, S., and Veld, K.V. (2005). Poverty and the Environment: Exploring the Relationship between Household Incomes, Private Assets, and Natural Assets. Center for Development Economics, Department of Economics, Delhi School of Economics, Working paper No. 134. pp. 1-48.

Pattanayak, S.K., Sills, E., \& Kramer, R.A. (2004). Seeing the Forest for Fuel. Environment and Development Economics, 9:155-179.

Perz, S.G., Carlos Arambur, U.C., and Bremner, J. (2005). Population, Land Use and Deforestation in the Pan Amazon Basin: A Comparison of Brazil, Bolivia, Colombia, 
Ecuador, Peru and Venezuela. Environment, Development and Sustainability, 7:2349.

Perz, S.G \& Walker, P.T. (2002). Households Life Cycles and Secondary Forests Cover among Small Farm Colonists in the Amazon. World Development, 30(6):1009-1027.

Quang, D.V. and \& T.N. (2006). Commercial Collection of NTFPs and Households Living in or Near the Forests: Case Study in Que, Con Cuong and Ma, Tuong Duong Ecological Economics, 60: 65-74.

Raashid, M., (1999). Resource Management Plan for the Swat Forest Range of Swat Forest Division (1999-2000 to 2013-14). Forest Management Center, NWFP Forest Department.

Rabbi. F., \& Bauer, S., (2007). How Sustainable use and Successful Forest Policies can be realized in Less Favoured Environments? Households Forest use Pattern, Economic Reliance and its Role in Community Welfare in Northern Pakistan. In Proceedings of USSEE conference "Creating Sustainability within our Midst" Challenges for $21^{\text {st }}$ century, held on 23-24 June, Pace University New York, United States.

Rabbi.F., Bauer, S., and Idalinya, J. (2010). Contribution of forest to rural inequlity reduction: present scope and future options for rural development and sustainable use of forests. International Journal of Sustainable Development and World Ecology, 17(1) 4-14.

Reardon, T.A. \& Vosti, S.A. (1995). Links between Poverty and Environment in Developing Countries.Asset Categories and Investment Poverty. World Development, 23:14951506.

Rome, S., (2005). Forestry in the Princely State of Swat and Kalam (North-West Pakistan).A Historical Perspective on Norms and Practices. IP6 Working Paper No.6.NCCR, North South, Switzerland. www.nccrpakistan.org/publications_pdf/Forests/Rome_Swat.pdf

Rowley, J. (1990). Linking Population to Conservation. Special Report, Pakistan. Earth Watch, 40:3-5.

Steimann, B. (2003). Decentralization and Participation in the Forestry Sector of NWFP, Pakistan-The Role of the State.Unpublished Master thesis, department of Geography University of Zurich. Forestry Systems, 52(2): 145-160.

Swinton, S.M., and Quiroz, .R. (2003). Is Poverty to Blame for Soil, Pasture and Forest Degradation in Peru Altipano? World Development, 31(11):1903-1919.

Takasaki, Y. Barham, B.L., and Coomes, O.T. (2001). Amazonian Peasants Rain Forest Use and Income generation: The Role of Wealth and Geographical Factors. Society and Natural Resources, 14 (18):291-308.

Takasaki, Y., Barham, B.L., and Coomes, O.T. (2004). Risk Coping Strategies in Tropical Forests; Floods, Illness, and Resource Extraction. Environment and Development Economics, Cambridge University Press, 9:203-224.

Vedeld, P., Angelsen, A., Sjaastad, E., and Berg, G.K. (2004). Counting on the Environment: Forest Incomes and the Rural Poor. Paper No. 98, Washington, DC, The World Bank Environment Department.

Wickramasinghe, A., M.R. Perez, and Blockhus J.M. (1996). Non-timber Forest Product Gathering in Ritigala Forest (Sri Lanka): Household Strategies and Community Differentiation. Human Ecology, 24 (4)-493-519.

WDI (2014). Rural environment and land use. www.wdi.worldbank.org/table/3.1

Wood, TS. Baldwin, S. (1985). Fuelwood and Charcoal Use in Developing Countries Ann. Rev. Energy, 10: 407-29. http://arjournals.annualreviews.org/doi/pdf 
Table 1: Results of the Logistic Regression for Households' Extraction of forest resources in Khyber Pakhtunkhwa

\begin{tabular}{|c|c|c|c|}
\hline Variables & Fuelwood & Timber & Free grazing \\
\hline Constant & $-13.99(5.38)^{* *}$ & $1.25(1.26)$ & $0.32(0.93)$ \\
\hline Age of household head (years) & $0.15^{*}(0.06)$ & $-0.08 * * *(0.02)$ & - \\
\hline Household head education (years) & $-0.24 *(0.13)$ & $0.02(0.04)$ & - \\
\hline Household size & $0.48 *(0.20)$ & $0.03(0.06)$ & $0.001(0.06)$ \\
\hline $\begin{array}{l}\text { Tenure Insecurity of forest } \\
\text { ownership }\end{array}$ & $2.88 *(1.48)$ & $2.49 * * *(0.49)$ & - \\
\hline Number of crop grown & $-1.63 * *(0.85)$ & - & - \\
\hline Distance to forest $(\mathrm{Km})$ & $-0.77 * *(0.31)$ & - & - \\
\hline Distance to town (Km) & $0.36 * *(0.12)$ & - & - \\
\hline Farm size (acres) & - & $0.34 * * *(0.11)$ & \\
\hline Use Substitute fuel & $-2.36 *(1.41)$ & - & - \\
\hline Planted tree on farm & $-2.26 *(1.10)$ & - & - \\
\hline Number of goats owned & $-0.38 *(0.15)$ & $-0.03(0.05)$ & $0.43 * * *(0.09)$ \\
\hline Resident in Miandam & $-2.40 *(1.50)$ & $0.94 *(0.43)$ & $-0.12(0.39)$ \\
\hline Resident in Bamburet & $1.82(2.01)$ & $-1.35 *(0.65)$ & $-.15(0.66)$ \\
\hline Share of off-farm income $(\%)$ & - & $-0.00(0.01)$ & $-0.04 * * *(0.13)$ \\
\hline Participation in extension & - & - & $-1.59 * * *(0.66)$ \\
\hline Log Likelihood & -15.45 & -87.30 & -91.178 \\
\hline $\operatorname{LR} \chi^{2}$ & $207 * * *$ & $72.23 * * *$ & $55.29 * * *$ \\
\hline Prob $>\chi^{2}$ & 0.000 & 0.000 & $0.000 * * *$ \\
\hline McFadden Pseudo $\mathrm{R}^{2}$ & 0.87 & 0.29 & 0.23 \\
\hline Number of observations & 180 & 180 & 180 \\
\hline
\end{tabular}

Notes: $* * *, * *$ and $*$ indicate significance at $1 \%, 5 \%$ and $10 \%$ probability level respectively

Note a: substitute fuel refers to kerosene, Liquid petroleum Gas (LPG), Livestock dung (manure), agricultural residues, electricity, biogas plant etc.

S.E are in Parentheses 
Table 2 : Results of the GLS Regression for Households' Extraction of forest resources in Khyber pakhtunkhwa

\begin{tabular}{ll}
\hline Variables & Total Quantity of Fuelwood Extracted Per Year Per Household \\
\hline Constant & $14567.84(5.30)^{* * *}$ \\
Number of Adult Literate Males & $-670.3181(-2.23)^{* *}$ \\
in the Household & $357.85(3.77)^{* * *}$ \\
Household size & $-1108.92(-2.23)^{* *}$ \\
Tenure security & $-431.30(-2.71)^{* * *}$ \\
Distance to forest $(\mathrm{Km})$ & $172.52(3.38)^{* * *}$ \\
Distance to town $(\mathrm{Km})$ & $-681.51(-4.17)^{* * *}$ \\
Total Landholding (acres) & $-1047.67(-2.03)^{* *}$ \\
Use Substitute fuel & $-27.01(-2.39)^{* * *}$ \\
Planted tree on farm & $570.82(1.01)$ \\
Resident in Miandam & $-5697.52(-8.22)^{* * *}$ \\
Resident in Bamburet & $-162.80(-5.96)^{* * *}$ \\
Share of off-farm income (\%) & \\
\hline Goodness of Fit Statistics & 0.90 \\
$\mathrm{R}^{2}$ & 0.89 \\
Adjusted R & 18.95 \\
AIC Criteria & 19.17 \\
SBC Criteria & $140.49 * * *$ \\
F-Statistic & 2.14 \\
Durban Watson & Notes: ***,** and * indicate significance at $1 \%, 5 \%$ and $10 \%$ probability level respectively \\
Note a: substitute fuel refers to kerosene, Liquid petroleum Gas (LPG), Livestock dung (manure), \\
agricultural residues, electricity, biogas plant etc. \\
Values in bracket are t-values
\end{tabular}

